\title{
THE EFFECT OF HAVING ANOTHER SEX PARTNER ONTHE RISK OF HIV INFECTION IN COUPLES IN MEDAN, NORTH SUMATERA
}

\author{
Aprilita Br. Sitepu, Namora Lumongga Lubis, \\ Fazidah Aguslina Siregar
}

Master Program in Public Health, Universitas Sumatera Utara

\begin{abstract}
Background: HIV infection and AIDS are the global public health problem. Having another sex partner may increase the risk of HIV infection. This study aimed to determine the effect of having another sex partner on the incidence of HIV infection in couples in Medan.

Subjects and Method: This was an analytic observational study with a case-control design. The study was conducted at RSUP H Adam Malik Medan, North Sumatera, from November to December 2017. A sample of 80 housewives was selected for this study by fixed disease sampling consisting of 40 HIV infected housewives and 40 HIV uninfected housewives. The dependent variable was HIV infection. The independent variable was having another sex partner. The data were collected by questionnaire and analyzed by chi-square test.

Results: Couples who had another sex partner had more risk of HIV infection than having no other sex partner $(\mathrm{OR}=7.34 ; 95 \% \mathrm{CI}=2.05$ to 26.19 ; $\mathrm{p}=0.002$ ).

Conclusion: Couples who have another sexual partner have an increased risk of HIV infection.
\end{abstract}

Keywords: HIV, housewive, having other sex partner

Correspondence:

Aprilita Br. Sitepu. Master Program in Public Health, Universitas Sumatera Utara. 